\title{
THE RELATIONSHIP BETWEEN ARM MUSCLE STRENGTH AND LEG MUSCLE STRENGTH TOWARDS 50-METER FREESTYLE SWIMMING SPEED
}

\author{
Johanna Matitaputty \\ Penjaskesrek Study Program Lecturer \\ Faculty of Teacher Training and Educational Sciences \\ Pattimura University, Maluku \\ *e-mail : jokematitaputty0@gmail.com
}

\begin{abstract}
This study aims to determine the relationship between arm muscle strength and leg muscle strength towards 50-meter freestyle swimming speed of Physical Education Students Major, at FKIP Unpatti Ambon. Based on the results of the analysis of leg muscle strength variables with a swimming speed of 50 meters crawl stroke of male students in Health and Sport Study Program of FKIP Unpatti Ambon $\mathrm{F}_{\text {count }}=3,61>\mathrm{F}_{\text {table }}(\mathrm{dk}=28$ and $\alpha=0,05)=1,70$ at the level $\alpha=0.05$ and means the null hypothesis (H0) is rejected. Based on the analysis of the variable arm muscle strength with a swimming speed of 50 meters crawl stroke of male students in Health and Sport Study Program of FKIP Unpatti Ambon, the results obtained $\mathrm{F}_{\text {count }}=3,47>\mathrm{F}_{\text {table }}(\mathrm{dk}=28$ and $\alpha=0,05)=1.70$ at the level $\alpha$ $=0,05$ and means the null hypothesis (H0) is rejected. Based on the analysis of the relationship between leg muscle strength, arm muscle strength, and swimming speed 50 meters crawl stroke of male students in Health and Sport Study Program of FKIP Unpatti Ambon, the result obtained $F_{\text {count }}$ $=14,99>\quad \mathrm{F}_{\text {table }}(\mathrm{dk}=28$ and $\alpha=0,05)=1,70$ at the level $\alpha=0,05$ and means the null hypothesis $(\mathrm{H} 0)$ is rejected. Thus, the stronger the leg muscles and arm muscles, the better the crawl stroke speed of students of the Health and Sport Study Program of FKIP Unpatti Ambon.
\end{abstract}

Keywords: Arm Muscle Strength, Leg Muscle Strength, Swimming Speed 50 Meter Freestyle

\section{Introduction}

Swimming is one of the activities in the pool (water) which is arranged in such a way that it produces an orderly movement. Such movements are the coordination of the movements of the feet, hand movements, and other body parts. the purpose of swimming is not solely to achieve achievement, but to achieve broader goals, including to: physical formation and development, fostering healthy living, maintaining physical fitness, and increasing body capacity, and safety.

Swimming is usually done by swimmers, and contested consists of four styles which include: 1) Crawl stroke, 2) breast stroke, 3) back stroke, 4) butterfly stroke. Each of the four styles each has its own difficulty level. Free style is swimming with chest facing the surface of the water. Both hands are alternately moved pedaling, while both legs are alternately whipped up and down up and down.

Freestyle is a swimming style that creates body movements moving on the surface of the water quickly (Nenggala, 2006). both arms are alternately moved further forward by pedaling, while both legs are alternately whipped up and down. when swimming freestyle, face position facing the surface of the water. breathing is performed when the arm is moved out of the water, when the body is tilted and the head is turned sideways. when taking a breath, swimmers can choose to look left or right.

Ermat Suryatna and Adang Suherman (2001: 67) explained that the whole basic freestyle swimming technique can be divided into: body position, arm movements, limbs, breathing, and coordination. In swimming speed is very necessary in order to enter finish quickly. Speed is a determining factor in all sports, one of which is swimming. 
Speed is the ability to make similar movements in a row in the shortest possible time; or the ability to travel long distances in time. so, speed does not only mean moving the whole body quickly, but can also be limited to moving the limbs, such as arms, legs, in the shortest possible time (Harsono, 2018: 148). In addition to the speed of strength is also very necessary to be able to mengauyun and move limbs such as limbs and arms for the body can move forward because without strength the swimmer can not move the limbs and arms to pedal and pull when swimming.

Strength is the ability of muscles to generate tension against a prisoner. Muscle is a network in the human body or animal that functions as an active means of movement that moves bone. Muscle strength is a very important component to improve overall physical condition, because 1) strength is the driving force of every physical activity, 2) strength plays an important role in protecting athletes / people from possible injury, 3) because with strength, athletes will be able to run faster, throwing or kicking further and more efficiently, hitting harder, 4) muscle strength can help strengthen joint stability (Harsono 2018: 6162).. limbs are the main means of motion in swimming to move the body. Movement can be done if there is mechanical energy available. Namely the energy obtained as a result of chemical metabolism that occurs in the body. Leg movements occur due to contraction of muscles or groups of muscles to overcome obstacles or weights. The burden can come from inside the body or from outside the body. From within the body in the form of one's own body weight, such as transferring body weight in swimming While from outside the body in the form of objects to be moved or used in sports activities.

Strength means the ability to expend maximum energy in one effort, the ability of strength means the occurrence of muscle contractions in humans, according to Thomas human muscle contractions there are three types of contractions namely; static, concentric and eccentric (Thomas R. Baechle and Barney R. G 2000:5), While speed is the ability to make movements in the shortest possible time. This is based on the notion of strength as a quality that allows the development of muscle tension in muscle contraction. Then the arm as part of the upper body, serves to make interesting movements, holding, and pushing an object. The arm is one of the upper limbs arranged according to the skeleton and muscles or a group of muscles that wrap it. There are 4 parts of the arm, namely: 1) Upper Arm, 2). Forearm, 3). Hands. Arm muscle strength is the ability of a group of arm and shoulder muscles in maximum contraction to overcome / fight the load.

According to Pate, arm muscles are muscles that are attached along the length of the arm bone, namely: (1) major pactoralis, (2) deltoids, (3) triceps brachii, (4) bicep brachii, (5) oracobrachialis, (6) brachialis , (7) brachioradialis, and (8) extensor carpi radialis langus (Frank S. Pyke 1980). Arm muscle strength is needed in doing movements such as: throwing, hitting, pushing, lifting, and pulling. These movements appear due to the contraction of muscles lengthening, shortening, moving away, approaching body parts, and circular movements in all directions in a $360^{\circ}$ angular range. Anatomically these movements are: (1) flexion, (2) extension, (3) abduction, (4) posterior abduction, (5) horizontal abduction, (6) lateral rotation, and (7) medial rotation. Swimming is a swinging arm that is anatomically a combination of horizontal-flexion-extension abduction. When doing freestyle swimming, the outer and inner muscle components contract, giving rise to rapid energy, the slowness of these muscles to contract. Thus the strength of the arm muscles is very important in doing push / paddle swimming freestyle quickly. The use of muscle strength groups according to the type of activities carried out. as well as the legs in freestyle swimming, they function as active motors for performing and mastering swimming techniques, namely: start movements, leg movements when swimming and reversal movements. In addition, the limbs also have a function as a buffer for the upper body and also functions as a tool to throw the body vertically or horizontally.

The skeletal system and the composition of the human muscles work together to produce movements that positively affect sports skills. Motion is a response to stimulation 
both from within and from outside. Motion in humans is caused by muscle contractions that move bones. So motion is the collaboration between bones and muscles.

Bones are called passive motors because they only control muscle control, whereas muscles are called active motors because they are able to contract, so they are able to move bones. Muscles work by contracting and relaxing, which require energy and involve chemicals. The three muscle groups are the parts that make up the leg muscles as a whole. The legs are lower limbs formed by 1) the thigh bone, 2) the shin, 3) the kneecap, 4) the leg bones (Hardianto Wibowo 1994: 11) . Legs as a means of movement function as a lever used to overcome resistance or increase speed and as the lowest part of the human body is a simple mechanical device.

\section{Research Method}

The method used in this study is a quantitative method with correlation and descriptive techniques. Where data is collected, arranged systematically, factual and meticulously, then the relationship between these variables is examined. The purpose of this research method is the extent to which variations in one variable are related to variations in other variables. The sample consisted of 30 students of Penjas, Pattimura University class of 2016.

\section{Results and Discussion}

\section{a. Swimming speed 50 meters freestyle}

The results of the 50 meter swimming freestyle (Y) swimming speed in the Physical Education students of FKIP Unpatti Ambon University obtained the lowest score of 33.05 seconds, and the highest score of 41.59 seconds so that the range was 8.54 seconds. The average value $\left(\mathrm{Y}^{-}\right)$was 37.16 seconds, the median was 37.03 seconds, the mode was 0 seconds, the standard deviation (s) was 2.53 and the variance was 6.41 .

Based on the raw data of the 50 meter freestyle swimming speed in the Pattimura University FKIP Physical Education students, the frequency distribution can be arranged as follows:

Table 3 : Frequency distribution of 50 meter freestyle swimming speed scores Male (Y) Physical Education students FKIP Pattimura University Ambon.

\begin{tabular}{|ccc|c|c|c|c|}
\hline \multicolumn{2}{|c|}{ Class Interval } & Lower Limit & Upper Limit & $\begin{array}{c}\text { Absolute } \\
\text { Frequency }\end{array}$ & $\begin{array}{c}\text { Relative } \\
\text { Frequency }\end{array}$ \\
\hline 33.05 & - & 34.47 & 33.045 & 34.475 & 6 & $20.0 \%$ \\
\hline 34.48 & - & 35.90 & 34.475 & 35.905 & 6 & $20.0 \%$ \\
\hline 35.91 & - & 37.33 & 35.905 & 37.335 & 4 & $13.3 \%$ \\
\hline 37.34 & - & 38.76 & 37.335 & 38.765 & 4 & $13.3 \%$ \\
\hline 38.77 & - & 40.19 & 38.765 & 40.195 & 7 & $23.3 \%$ \\
\hline 40.20 & - & 41.62 & 40.195 & 41.625 & 3 & $10.0 \%$ \\
\hline \multicolumn{2}{|r|}{ Total } & & & 30 & $100 \%$ \\
\hline
\end{tabular}

Based on data from 30 research samples of male students from the Physical Education Dept of Pattimura University in Ambon, the results of each sample were compared with the average. It turns out that those who obtained a 50-meter Freestyle Swimming Pool score 
were above the average group of 12 people (40\%) below the average group of 14 people $(46.7 \%)$ and 4 people (13.3\%) are in the average group.

\section{b. Leg Muscle Strength}

The results of research on Leg Muscle Strength (X_1) Physical Education students of FKIP Unpatti Ambon obtained the lowest score of $58 \mathrm{~kg}$, the highest score of $165 \mathrm{~kg}$, so that the range of $107 \mathrm{~kg}$. The average value $(\mathrm{X})$ was $98.6 \mathrm{~kg}$, median was $95 \mathrm{~kg}$, mode was $89 \mathrm{~kg}$, standard deviation (s) was $22.85 \mathrm{~kg}$ and variance was 522.25 .

Based on raw data about Leg Muscle Strength (X_1), the male students of FKIP Unpatti Ambon physical education can be arranged as follows:

Table 4: Frequency distribution of leg muscle strength scores (X_1) Male physical education student FKIP Unpatti Ambon

\begin{tabular}{|ccc|c|c|c|c|}
\hline \multicolumn{2}{|c|}{ Class Interval } & Lower Limit & $\begin{array}{c}\text { Upper } \\
\text { Limit }\end{array}$ & $\begin{array}{c}\text { Absolute } \\
\text { Frequency }\end{array}$ & $\begin{array}{c}\text { Relative } \\
\text { Frequency }\end{array}$ \\
\hline 58 & - & 75 & 57.5 & 75.5 & 5 & $16.7 \%$ \\
\hline 76 & - & 93 & 75.5 & 93.5 & 9 & $30.0 \%$ \\
\hline 94 & - & 111 & 93.5 & 111.5 & 9 & $30.0 \%$ \\
\hline 112 & - & 129 & 111.5 & 129.5 & 4 & $13.3 \%$ \\
\hline 130 & - & 147 & 129.5 & 147.5 & 2 & $6.7 \%$ \\
\hline 148 & - & 165 & 147.5 & 165.5 & 1 & $3.3 \%$ \\
\hline \multicolumn{2}{|c|}{ Total } & & & & 30 & $100 \%$ \\
\hline
\end{tabular}

Based on data from 30 research samples of male students from the Physical Education Department of FKIP Unpatti Ambon, the results of each sample were compared with the average. It turned out that those who got leg muscle strength scores above the group average were 14 people $(46.7 \%)$. below the average group of 7 people $(23.3 \%)$, and 9 people (30.0\%) were in the average group.

\section{c. Arm Muscle Strength}

The results of research on Arm Muscle Strength (X_2) FKIP Unpatti Ambon students obtained the lowest score of $20 \mathrm{~kg}$, the highest score of $47 \mathrm{~kg}$, so that the range of $27 \mathrm{~kg}$. The average value $\left(\mathrm{X}^{\bar{T}}\right.$ ) was $29.4 \mathrm{~kg}$, the median was $28.5 \mathrm{~kg}$, the mode was $20 \mathrm{~kg}$, the standard deviation (s) was $7.40 \mathrm{~kg}$ and the variance was 54,73 .

Based on raw data about arm muscle strength (X_2), male students of the FKIP Unpatti Ambon Physical Education Study Program, the frequency distribution can be arranged as follows: 
Table 5: Frequency distribution of arm muscle strength scores (X_2) Male students FKIP Unpatti Ambon

\begin{tabular}{|ccc|c|c|c|c|}
\hline \multicolumn{2}{|c|}{ Class Interval } & & Lower Limit & Upper Limit & $\begin{array}{c}\text { Absolute } \\
\text { Frequency }\end{array}$ & $\begin{array}{c}\text { Relative } \\
\text { Frequency }\end{array}$ \\
\hline 20 & - & 24 & 19.5 & 24.5 & 10 & $33.3 \%$ \\
\hline 25 & - & 29 & 24.5 & 29.5 & 6 & $20.0 \%$ \\
\hline 30 & - & 34 & 29.5 & 34.5 & 5 & $16.7 \%$ \\
\hline 35 & - & 39 & 34.5 & 39.5 & 6 & $20.0 \%$ \\
\hline 40 & - & 44 & 39.5 & 44.5 & 2 & $6.7 \%$ \\
\hline 45 & - & 49 & 44.5 & 49.5 & 1 & $3.3 \%$ \\
\hline \multicolumn{2}{|r|}{ Total } & & & 30 & $100 \%$ \\
\hline
\end{tabular}

Based on data from 30 research samples of male students from the Physical Education Department of FKIP Unpatti Ambon, the results of each respondent were compared with the average. It turns out that those who obtained an Arm muscle strength score above the group average were 10 people (33.3\%). below the average group of 14 people $(46.7 \%)$, and 6 people $(20.0 \%)$ are in the average group.

\section{d. Testing Requirements Analysis}

Since the data processing in this study uses statistical tests with correlational analysis techniques, it is necessary to test the analysis requirements, so the results of the regression and correlation can be used to draw conclusions, in this study the intended test requirements include normality tests and homogeneity variance tests.

\section{Normality Test}

To see whether the data obtained from each of the research variables is normal or not, a normality test is performed using the Liliefors test. The criteria used in determining the normality test results are: the data is otherwise normally distributed if $\mathrm{L}_{\text {count }} \leq \mathrm{L}_{\text {table }}$ or otherwise the data is declared not normally distributed if $\mathrm{L}_{\text {count }}>\mathrm{L}_{\text {table. }}$. While what is meant by $\mathrm{L}_{\text {count }}\left(\mathrm{L}_{\mathrm{o}}\right)$ is the difference between the largest absolute price between the standard score opportunity and the standard score proportion $(|\mathrm{F}(\mathrm{zi})-\mathrm{S}(\mathrm{zi})|)$. For more details, the normality calculation results of the variables studied will be presented using the liliefors test at the significance level $\alpha=0.05$.

\section{Test normality error estimated $Y_{1}$ regression}

Swimming speed regression equation 50 meters freestyle male students Physical Education FK Unpatti Ambon. based on the results of the liliefors normality test calculation, the price is obtained $\mathrm{L}_{\mathrm{o}}=0,1047$. Where is the critical value $\mathrm{L}_{\mathrm{o}}$ in the Liliefors table for sample size $(n)=30$ with $\alpha=0.05$, a value of 0.161 is obtained, compared to the value $\mathrm{L}_{\text {count }}<\mathrm{L}_{\text {table }}$, From these results it can be concluded that the data are normally distributed.

\section{Test normality for estimated error of regression $X_{1}$}

Leg muscle strength regression equation $\left(\mathrm{X}_{1}\right)$, male students of Physical Education FKIP Unpatti Ambon as follows: Based on the results of the calculation of the liliefors normality test obtained by the price $L_{o}=0,1047$, Where is the critical value $L_{o}$ in the 
Liliefors table for sample sizes $(\mathrm{n})=30$ with $\alpha=0,05$ a value of 0,161 , when compared to value $\mathrm{L}_{\text {count }}<\mathrm{L}_{\text {table }}$, so it can be concluded that the data is normally distributed.

Test normality for estimated error of regression $X_{2}$

Regression equation of arm muscle strength $\left(\mathrm{X}_{2}\right)$, male students of Physical Education FKIP Unpatti Ambon as follows: Based on the results of the liliefors normality test results obtained $\mathrm{L}_{0}=0,0935$, Where is the critical value $\mathrm{L}_{\mathrm{o}}$ in the Liliefors table for sample size (n) $=30$ with $\alpha=0.05$, a value of 0.161 is obtained, compared to the value $\mathrm{L}_{\text {count }}<\mathrm{L}_{\text {table }}$, so it can be concluded that the data is normally distributed.

The summary of normality test results for the two regression equations above is presented in the table below:

Table 7: Normality Test Results

\begin{tabular}{|l|c|c|c|}
\hline \multicolumn{1}{|c|}{ Variabel } & L $_{\text {count }}$ & $\begin{array}{c}\text { Ltable } \\
(\mathbf{0 , 0 5})\end{array}$ & Testing Results \\
\hline Leg Muscle Strength $\left(\mathrm{X}_{1}\right)$ & 0,1047 & 0,161 & Normal \\
Arm Muscle Strength $\left(\mathrm{X}_{2}\right)$ & 0,0935 & 0,161 & Normal \\
Swimming Speed Y & 0,0915 & 0,161 & Normal \\
\hline
\end{tabular}

\section{Homogeneity Variance Test}

To test homogeneity, the Bartlett test was used. Homogeneity test in this study is to test the combined homogeneity of population variance, namely HO: $\sigma 12=\sigma 22=\sigma 32=$ $\sigma 42$. The results of the combined homogeneity test for population variance are summarized as in the table below.

Table 8: Homogeneity test calculation with Bartlett test

\begin{tabular}{|c|c|c|c|c|c|c|}
\hline Sample & $\mathbf{D b}$ & $\mathbf{1 / d b}$ & $\mathbf{s i}^{\mathbf{2}}$ & $\mathbf{l o g} \mathbf{s i}^{\mathbf{2}}$ & $\mathbf{d b} \log \mathbf{s i}^{\mathbf{2}}$ & $\mathbf{d b ~ \mathbf { s } _ { \mathbf { i } } { } ^ { \mathbf { 2 } }}$ \\
\hline $\mathrm{Y}$ & 30 & 0,03333 & 97,96 & 1,991 & 59,732 & 2938,931 \\
\hline $\mathrm{X}_{1}$ & 30 & 0,03333 & 100,44 & 2,002 & 60,057 & 3013,138 \\
\hline $\mathrm{X}_{2}$ & 30 & 0,03333 & 100,48 & 2,002 & 60,062 & 3014,345 \\
\hline Total & 120 & & & & 239,752 & 11943,655 \\
\hline
\end{tabular}

Test criteria: "Reject the hypothesis H0 if $\geq(1-\alpha)(k-1)$, where $(1-\alpha)(k-1)$ is obtained from the list of chi squared distributions with probability $(1-\alpha)$ and $\mathrm{dk}=(\mathrm{k}-1)$, The combined homogeneity test results of population variance are summarized as in the table below.

Table 9. Homogeneity test calculation with Bartlett test

\begin{tabular}{|c|c|c|c|c|}
\hline Hypothesis & Dk & $\mathbf{X}_{\mathbf{0}}^{2}$ & $\begin{array}{c}\mathbf{X}_{\mathbf{0}}^{2}(\boldsymbol{\alpha}= \\
\mathbf{0 , 0 5})(\mathbf{3})\end{array}$ & Conclusion \\
\hline $\begin{array}{c}\mathrm{H}_{\mathrm{O}}: \sigma_{1}{ }^{2}=\sigma_{2}{ }^{2}=\sigma_{3}{ }^{2} \\
\mathrm{H}_{\mathrm{i}}: \sigma_{1}{ }^{2}=\sigma_{2}{ }^{2}=\sigma_{3}{ }^{2}\end{array}$ & 3 & 0.006 & 7.81 & homogeneously \\
\hline
\end{tabular}


Information :

$\mathrm{H} 0=$ null hypothesis $(0)$

$\mathrm{Hi}=$ Alternative hypothesis

$\sigma 12=$ Variance of leg muscle strength variable

$\sigma 22=$ Variance of arm muscle strength variable

$\sigma 32=$ Variance of 50 meter freestyle swimming speed

$\mathrm{dk}=$ degree of freedom

$=$ Chi-squared calculation results

$(\alpha=0.05)(2)=$ Chi-square table with a significant level $\alpha=0.05$.

\section{Test of Significance and Linearity}

To determine the regression form between the independent variable (X) and the dependent variable $(\mathrm{Y})$ through the linearity test. The linearity test will test the null hypothesis (H0): The form of the linear regression coefficient. Testing this hypothesis with the $\mathrm{F}$ test.

The Criteria: "Reject the hypothesis that linear regression, if the F statistic for matched tuna obtained from research is greater than the $\mathrm{F}$ table based on the chosen real level and the corresponding dk".

The calculation results of the linearity regression test Swimming Speed 50 Meter Freestyle (Y) on Leg Muscle Strength (X1) can be summarized in the following table:

Table 10. Regression linearity test $\hat{Y}=22.21+0.556 \mathrm{X} 1$

\begin{tabular}{|l|c|c|c|c|c|}
\hline \multicolumn{1}{|c|}{$\begin{array}{c}\text { Source } \\
\text { Variance }\end{array}$} & Dk & JK & RJK & $\mathbf{F}_{\text {Count }}$ & $\mathbf{F}_{\text {table }}$ \\
\hline Tuna Match & 20 & 1489,81 & 74,49 & 13,00 & 3,44 \\
Error & 8 & 450,25 & 56,28 & & \\
\hline
\end{tabular}

From the calculation results obtained Fcount $=13.00$ and F_Tabel $(\alpha=0.05 ; 1 / 28)=$ 3.44. Thus it can be concluded that the regression equation forms a linear regression (significant). The results of the calculation of the 50 meter freestyle (Y) swimming speed regression linearity test for arm muscle strength (X2) can be summarized in the following table:

Table 11. Regression linearity test $\hat{Y}=22.91+0.542 \mathrm{X} 2$

\begin{tabular}{|l|c|c|c|c|c|}
\hline \multicolumn{1}{|c|}{$\begin{array}{c}\text { Source } \\
\text { Variance }\end{array}$} & Dk & JK & RJK & $\mathbf{F}_{\mathbf{0}}$ & $\mathbf{F}_{\mathbf{t}}$ \\
\hline Tuna Match & 14 & 705,61 & 50,40 & 0,55 & 2,55 \\
Error & 14 & 1279,78 & 91,41 & & \\
\hline
\end{tabular}

From the calculation results obtained $\mathrm{F} \neg 0=0.55$ smaller than $\mathrm{F} \_$Tabel $(\alpha=0.05 ; 1 / 28)$ $=2.55$. Thus it can be concluded that the swimming speed of 50 meters over the arm muscle strength is linear. 


\section{Test the Significance of Regression}

To determine the direction of regression between the independent variable $(X)$ and the dependent variable $(\mathrm{Y})$ through the test of the significance of regression. The significance of the regression test will test the null hypothesis $(\mathrm{H} 0)$ : the direction of the regression coefficient, Testing the hypothesis with the $\mathrm{F}$ test.

Test Criteria: "Reject the hypothesis that the coefficient of regression direction does not mean, if the F statistics obtained from the study are greater than the F table based on the chosen real level and the corresponding dk". The results of the calculation of testing the significance of the regression results swimming speed of 50 meters freestyle $(\mathrm{Y})$ on the strength of leg muscles (X1) can be briefly seen in the following table:

Table 13. Significance Test Results of Simple Linear Regression $\hat{Y}=22.21+0.556$ $\mathrm{X} 1$

\begin{tabular}{|l|c|c|c|c|c|}
\hline \multicolumn{1}{|c|}{$\begin{array}{c}\text { Source of } \\
\text { Variance }\end{array}$} & $\mathbf{D k}$ & $\mathbf{J K}$ & $\mathbf{R J K}$ & $\mathbf{F}_{\mathbf{0}}$ & $\mathbf{F}_{\mathbf{t}}$ \\
\hline \multicolumn{1}{|c|}{ Total } & 30 & 77741,00 & & & \\
\hline $\operatorname{Reg}(\mathrm{a})$ & 1 & 74900,03 & & & \\
$\operatorname{Reg}(\mathrm{b} / \mathrm{a})$ & 1 & 900,91 & 900,91 & 13,00 & 4,20 \\
Sisa & 28 & 1940,06 & 69,29 & & \\
\hline
\end{tabular}

From the calculation results obtained F_ $0=13.00$ while $F_{-}$Tabel $(\alpha=0.05 ; 1 / 28)=$ 4.20. It turns out that the value of $F_{-} 0$ is greater than F_t, so it can be concluded that the regression of 50 meter freestyle swimming velocity on the leg muscle strength direction of the regression coefficient is meaningful. The results of calculation of the significance of 50 meter freestyle (Y) swimming speed regression on arm muscle strength (X2) can be summarized in the following table:

Table 14. Simple Linear Regression Significance Test Results

$$
\hat{Y}=22,91+0,542 X_{2}
$$

\begin{tabular}{|l|c|c|c|c|c|}
\hline \multicolumn{1}{|c|}{$\begin{array}{c}\text { Source of } \\
\text { Variance }\end{array}$} & Dk & JK & RJK & $\mathbf{F}_{\mathbf{0}}$ & $\mathbf{F}_{\mathbf{t}}$ \\
\hline Total & 30 & 77741,00 & & & \\
\hline Reg (a) & 1 & 74900,03 & & & \\
Reg (b/a) & 1 & 855,57 & 855,57 & 12,07 & 4,20 \\
Sisa & 28 & 1985,39 & 70,91 & & \\
\hline
\end{tabular}

From the calculation results obtained F_ $0=12.07$ while Ftable $(\alpha=0.05 ; 1 / 28)=4.20$. It turns out that the value of $F_{-} 0$ is greater than $F_{-} t$, so it can be concluded that the 50meter freestyle swimming speed regression of the arm muscle strength in the direction of the regression coefficient is meaningful. While the linear regression test of death between the results of leg muscle strength tests (X1), arm muscle strength (X2), together with a swimming speed of 50 meters freestyle $(\mathrm{Y})$. 
Test criteria: "If the F calculated from the formula exceeds the $\mathrm{F}$ table from the $\mathrm{F}$ distribution list with the chosen significance level, then it is concluded that the regression is meaningful. The results of testing calculations can be summarized in the following table:

Table 16. Linearity Regression Test $\mathrm{Y}=-1096+0.280 \mathrm{X} 1+0.276 \mathrm{X} 2$

\begin{tabular}{|l|c|c|c|c|c|}
\hline \multicolumn{1}{|c|}{$\begin{array}{c}\text { Source of } \\
\text { Variance }\end{array}$} & $\mathbf{d b}$ & $\mathbf{J K}$ & $\mathbf{R J K}$ & $\mathbf{F}_{\mathbf{0}}$ & $\mathbf{F}_{\mathbf{t}}$ \\
\hline Total & 30 & 77741,000 & & & \\
\hline Regresi (a) & 1 & 74900,033 & & & \\
Residu (b/a) & 3 & 1800,274 & 600,091 & 14,992 & 2,89 \\
Sisa & 26 & 1040,693 & 40,027 & & \\
\hline
\end{tabular}

From the calculation results obtained F_ $0=14.992$ while Ftable $(\mathrm{dk}=26$ and $\alpha=0.05)$ $=2.89$. It turns out that $F_{-} 0$ is greater than $\bar{F}_{-} t$, so it can be concluded that the regression of leg muscle strength, arm muscle strength, self-confidence, together - swimming speed of 50 meters freestyle the direction of regression is significant / significant.

In general, the analysis of the leg muscle strength variable with a swimming speed of 50 meters freestyle for male students of FKIP Unpatti Ambon Physical Education, the results of Fcount $=3.61>$ Ftable $(\mathrm{dk}=28$ and $\alpha=0.05)=1.70$ at level $\alpha=0.05$ and means the null hypothesis (H0) is rejected, so there is a relationship between leg muscle strength (X1) with a swimming speed of 50 meters freestyle (Y).

Te results show that analysis of the variable arm muscle strength with a swimming speed of 50 meters freestyle for male students of the FKIP Unpatti Ambon Physical Education, the Fcount $=3.47>$ Ftable $(\mathrm{dk}=28$ and $\alpha=0.05)=1.70$ at the $\alpha$ level $=0.05$ and means the null hypothesis ( $\mathrm{H} 0)$ is rejected, so there is a relationship between arm muscle strength (X2) with a swimming speed of 50 meters freestyle (Y).

Based on the results of the analysis of the relationship between leg muscle strength, arm muscle strength, and swimming speed 50 meters freestyle in male students FKIP Unpatti Ambon, the results obtained Fcount $=14.99>$ Ftable $(\mathrm{dk}=28$ and $\alpha=0.05)=1.70$ at the level of $\alpha=0.05$ and means the null hypothesis (H0) is rejected, so there is a relationship between leg muscle strength (X1), arm muscle strength (X2), with a swimming speed of 50 meters freestyle (Y).

\section{Conclusion}

The results showed there was a positive relationship between leg muscle strength and swimming speed of 50 meters freestyle of male students from the Physical Education FKIP Unpatti Ambon. This means the stronger the leg muscle strength the better the speed in doing 50 meter freestyle relaxation. Likewise, the weaker the muscle strength of one's limbs, the lower the swimming speed of the 50-meter freestyle. Thus leg muscle strength is one of the variables that is strongly associated with 50-meter freestyle swimming. This conclusion implies that in order to increase the swimming speed of 50 meters freestyle in addition to technical factors, it is also necessary to develop leg muscle strength through physical training in muscle strength in accordance with the increase in leg muscle strength.

The results showed there was a positive relationship between arm muscle strength and swimming speed of 50 meters freestyle of male students from the Physical Education FKIP Unpatti Ambon. This means that the stronger the arm muscle strength the better the speed in doing 50 meter freestyle relaxation. Likewise, the weaker the muscle strength of one's arms, the lower the swimming speed of the 50-meter freestyle. Thus the strength of the arm 
muscles is one of the variables that is strongly associated with 50-meter freestyle swimming. This conclusion implies that in order to increase the swimming speed of 50 meters freestyle in addition to technical factors, it is also necessary to develop arm muscle strength through physical strength training in a dose that is consistent with an increase in arm muscle strength.

\section{References}

Ermat Suryatna dan Adang Suherman, Renang Kompetitif untuk SLTP (Jakarta: Depdiknas, Dikdasmen, $2001: 67$ )

Nenggala,A. K. 2006 (Pendidikan Jasmani,Olahraga, dan Kesehatan, Bandung: PT. Grafindo. Media Pratama.

Thomas, David G, Renang Tingkat Pemula (Jakarta: Raja Garfindo Persada, 1996: v)

Http://www.crayonpedia.org/mw/Kategori: Sistem_Gerak_Pada_Manusia_11.1" Diakses pada tanggal 25 januari 2013.

Hardianto Wibowo, Anatomi Ostologi dan alat gerak (Jakarta: IKIP Jakarta, 1994 : 11),

Thomas R. Baechle and Barney R. G. Strength and conditioning specialist, terj R. Siregar (Jakarta: Raja Grafindo. 2000: 5)

Frank S. Pyke, Toward Better Coaching (Canberra: Australian Goverment Publishing Service, 1980: 30),

Russel R Pate, Bruce Mc Clenahan, dan robert rotella, op.cit., p. 151 